\title{
NICKEL MINERALIZATION IN ZIMBABWE
}

by

\section{J.M. Clutten, R.P. Foster and A. Martin}

Nickel constitutes an important factor in Zimbabwe's economy although at present the country has only five operating mines which are relatively small by world standards. Three of the local organizers of a forthcoming IGCP International Workshop on the geology and exploration for nickel, copper, and platinum deposits, * review the latest concepts on the origin and occurrence of nickel in Zimbabwe and the potential for finding new deposits.

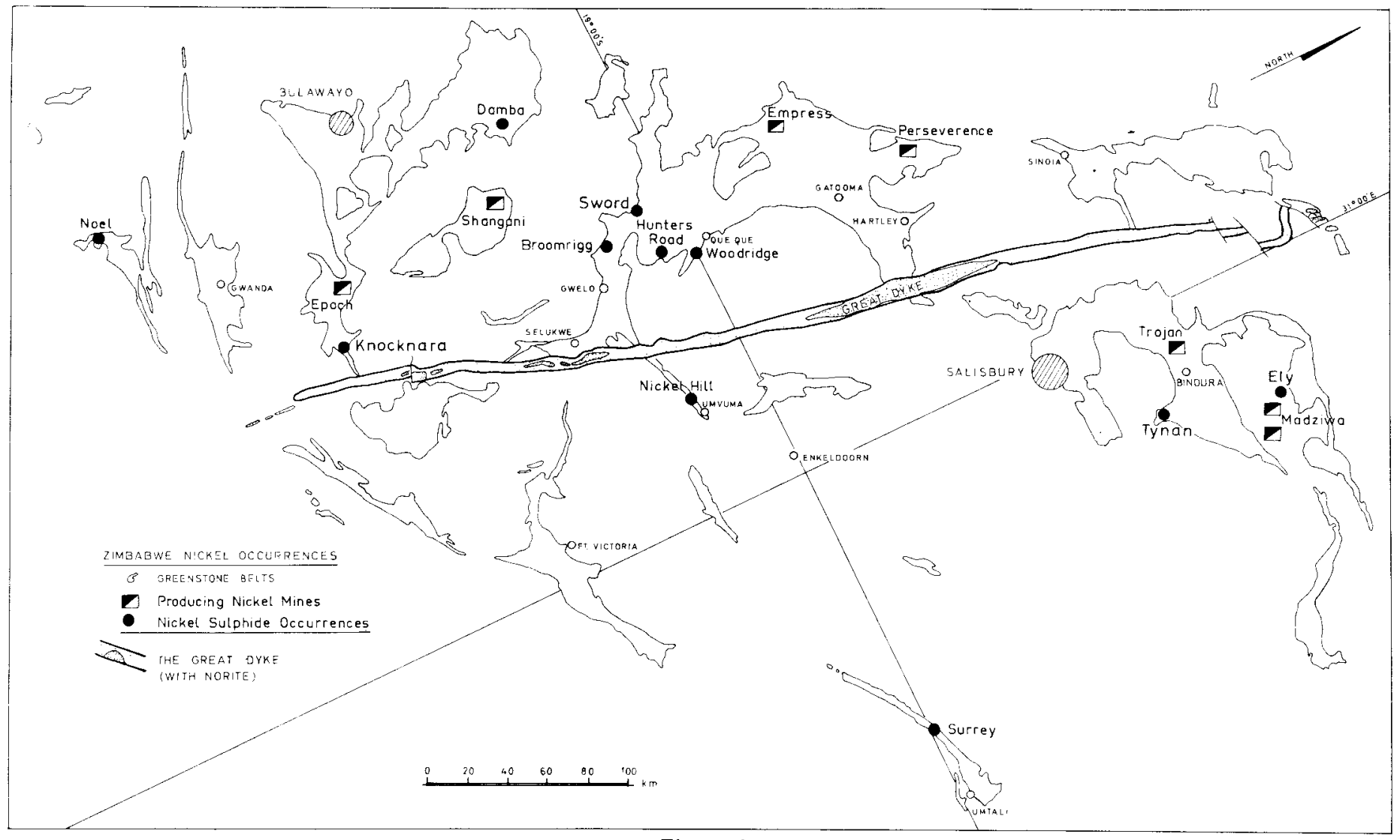

\section{Introduction}

The annual production of nickel in Zimbabwe is small (14000 tonnes) by world standards (Fig. 1), but the metal plays an important factor in the country's economy. While production of nickel concentrate was first recorded in 1935 from a small hydrothermal deposit (the Noel Mine) in SW Zimbabwe, the refractory nature of the ore precluded any large scale development. The discovery of several nickel deposits between 1955 and 1969 and the subsequent export of metallic nickel around 1965 led to substantial production, which has risen steadily ever since.

Historically, nickel has not commanded much attention in Zimbabwe since the mineral wealth of the country was discovered by individual prospectors and often exploited by small companies. They tended to concentrate their efforts on gold and other "high return" base metals; the exploitation of nickel remained the preserve of the larger companies until the 1950's, when company-based exploration was substantially increased and when three of the six major producers in the last decade were discovered by systematic exploration.

Figure 1.

Although the exploration policies of the mining companies differ slightly, most take out Exclusive Prospecting Orders which are granted by the State in which all mineral rights are vested.

The primary exploration technique used in Zimbabwe is geochemistry, with sampling both on a grid pattern and from stream sediments. This is usually done in conjunction with geological mapping, and in some cases, with geophysical surveys. Selected, smaller areas are then studied in greater detail using the same techniques with perhaps more sophisticated geophysical work (induced polarization, electro-magnetics, self-potential, gravity, and magnetics). Any anomalies are then drilled or trenched. Finally, bulk samples are obtained for ore dressing and metallurgical tests.

During the '60's and early '70's, any surface nickel anomalies without coincident copper were ignored since the two metals were generally found together elsewhere in the world. High nickel values alone were thought to merely reflect serpentinites at depth. This policy, however, has changed recently

* The Workshop, to be held July 20-30, 1981, has been organized under the auspices of IGCP Project 161 (Sulphide deposits in mafic and ultramafic rocks), and is being supported by Unesco, the Commonwealth Srience Council and a local Working Group comprising the Institute of Mining Research and the Department of Geology, University of Zimbabwe, as well as the Geology, Metallurgy and Mining Sub-Committee of The Scientific Council of Zimbabwe. The prime objective of the Workshop is to provide African geologists with an opportunity to debate the latest concepts regarding $\mathrm{Ni}$ and $\mathrm{Pt}$ orebodies. Instructors will include Prof. A.J. Naldrett (Canada), Leader of IGCP Project 161, and Prof. H. Papunen (Finland); representatives of over 15 African countries are expected to participate. 
and many of the early-found anomalies are currently being re-examined.

At present, there are five nickel mines operating in Zimbabwe, all of which are fairly small and of low grade compared, for example, to Australian or Canadian deposits. Low operating costs and a sympathetic tax structure has tended to favour their exploitation to an extent that might not have been possible in most developed countries.

The locations of the five current producers (Trojan, Shangani, Empress, Madziwa, and Epoch Mines) are shown in Figure 2. Perseverance Mine ended its ten-year life at the end of 1980 , while the Noel Nickel Mine recorded a sporadic production of 4657 tonnes of concentrate between 1935 and 1963, with half of this being mined in 1939. There are at least eleven other known nickel sulphide deposits which have been (or are being) examined, as well as several small lateritic deposits and the nickeliferrous platinoid horizons of the Great Dyke which contain large resources of the metal.

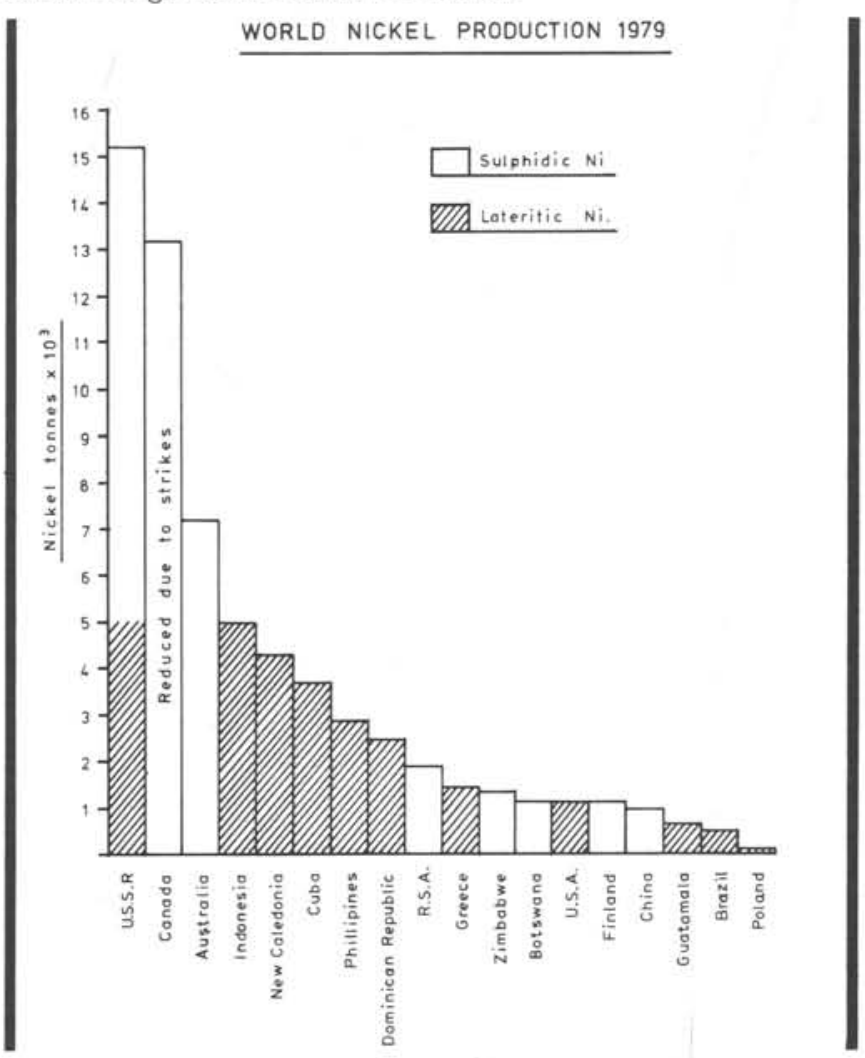

Figure 2.

\section{Regional Setting}

All of these deposits are located in the Rhodesian Craton* of Zimbabwe and most occur within rocks of komatiitic composition. The latter, whether intrusive or extrusive, are considered to form an integral part of the Archaean greenstone stratigraphy (Williams, 1979). The exceptions are the Madziwa occurrences which are surrounded by granite, the hydrothermal deposits of the Noel Mine and the Great Dyke. The status of the Empress mine is not clear.

In general, there appears to be a clear stratigraphic control of the nickel mineralization within greenstone belts, and by far the greater number of known nickel deposits, including three of the larger producing mines, occur at a single broad stratigraphic level. The stratigraphy, summarized in Table 1, has been compiled by Wilson (1979) as part of a craton-wide correlation exercise between discrete greenstone belts. It differs from the stratigraphy of Williams (1979).

The Upper Greenstones of the Bulawayan are considered to be approximately $2700 \mathrm{ma}$ old (Wilson, 1979). The base is marked in places by a thin sedimentary unit containing some sulphide facies iron-formation. This is overlain by a koma-
TABLE 1

Stratigraphy of Greenstone Belts (after Wilson, 1979)

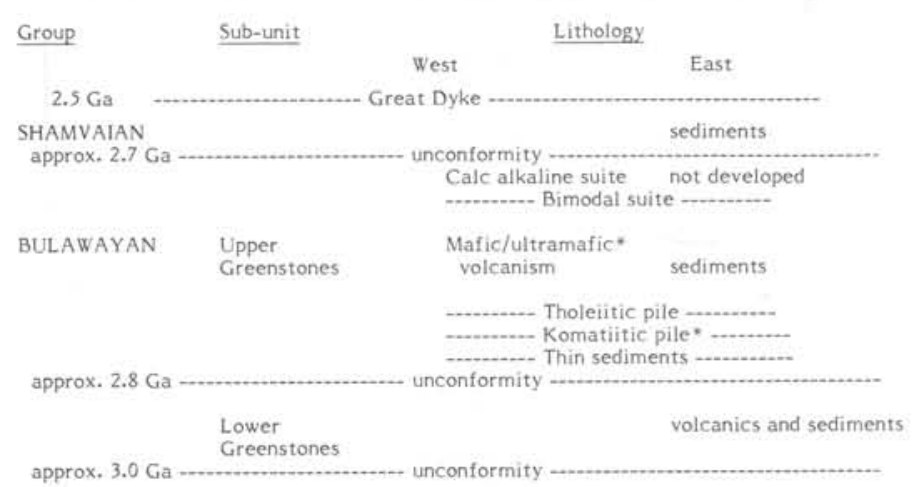

SEBAKWIAN

approx. $3.5 \mathrm{Ga}$

volcanics and sediments

*nickel deposits occur at these stratigraphic levels.

tiitic sequence up to $1 \mathrm{~km}$ thick (Nisbet et al, 1977) which contains the majority of the known nickel deposits in Zimbabwe including the Trojan, Shangani and Epoch Mines. It is succeeded by a 5-7 km thick tholeiitic pile.

Above these areally extensive mafic and ultramafic rocks is a bimodal mafic-felsic volcanic unit with an eastern facies of essentially sedimentary rocks. At the top of the stratigraphy is a calc-alkaline suite representing the final episode of large-scale Archaean volcanism which is confined to the north-western part of the craton. The former Perserverance Mine is located within komatiitic flows and sills of the bimodal suite, while the Empress Mine deposit is within a differentiated complex which intruded the calc-alkaline suite. Because there are no komatiitic flows within the calcalkaline suite, the Empress intrusion cannot be considered to be part of the stratigraphy.

The nickel minerals occurring in the Zimbabwean deposits are commonly sulphides, with the exception of Noel Mine where arsenical ores are present. The common major minerals are pyrrhotite, pentlandite, and millerite with minor violarite and polydymite in some deposits. Copper occurs mainly as chalcopyrite, and cobalt as cobaltic gersdorffite and cobaltic pentlandite. The platinum group and other precious metals are also recovered, but little is known of their mineralogy. The relative proportions of nickel and copper vary from 12:1 to $20: 1$ in the ultramafic ores whereas a $5: 1$ to $2: 1$ ratio and a 2:3 ratio are present at Madziwa and Empress respectively.

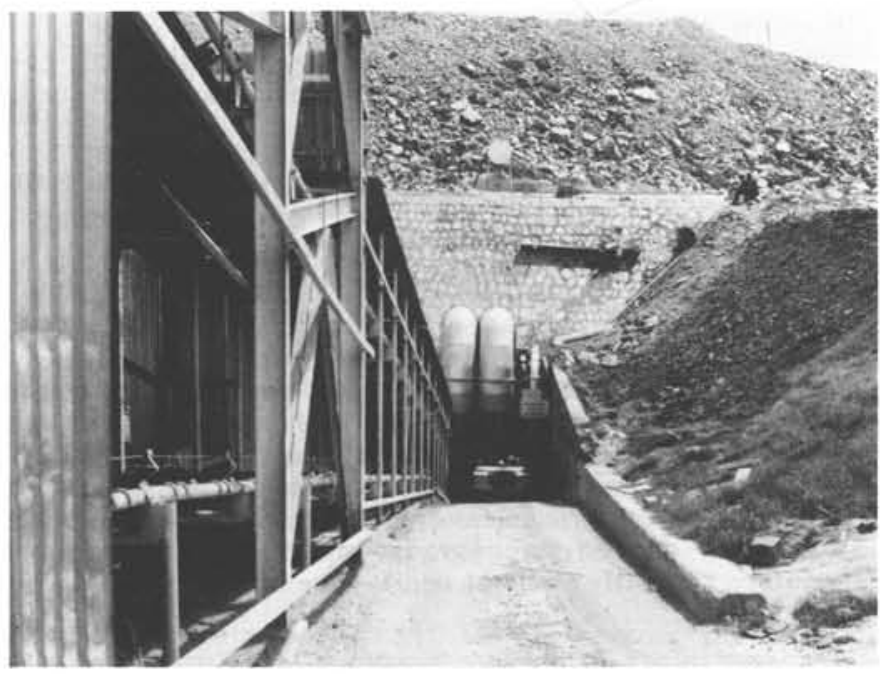

The main access to Shangani Mine, Zimbabwe.

*Rhodesian Craton, a geological name entrenched in the literature, is retained in this paper and refers to the Archaean terrain of Zimbabwe. 
Some of the nickel and a smaller amount of the copper are locked into the silicate lattice and is not economically recoverable with current technology. A further $10 \%$ of the sulphide is lost during concentration and the ultimate recovery on most mines varies between $65 \%$ and $75 \%$ for nickel and $80-90 \%$ for copper. Those ores of komatiitic affinity are also plagued by a high talc component in the gangue which has to be depressed by additional reagents in an alkaline medium, thus increasing beneficiating costs. The sulphide concentrates from the five producing mines are sent to two smelters at Bindura and Gatooma where the reduction to metal of particularly high grade is achieved.

\section{Individual Deposits}

The following brief descriptions of individual deposits are taken from both published and unpublished papers, though the amount of information available on any particular deposit of ten bears little relation to its size or importance.

\section{Trojan Nickel Mine}

This mine lies $10 \mathrm{~km} \mathrm{~S}$ of Bindura within the Mazoe greenstone belt. It is located within the basal units of the Upper Greenstones, where the ultramafic host overlies pillowed mafic lavas with a prominent banded iron formation marking the contact (Chimimba, 1981). Iron-formation is interlayered with the ore-bearing serpentinites and talc-carbonate rocks, and the whole assemblage is inclined very steeply to the north and has suffered amphibolite grade metamorphism.

There are two main and several minor orebodies at Trojan which contain a total reserve of some 13 million tonnes of ore with an average tenor of $0.68 \%$ nickel. The main orebodies are juxtaposed stratigraphically one above the other, which has led to the speculation that these could be hosted by the limbs of a large isoclinal fold.

Three types of ore have been recognized at Trojan and termed massive ore, partly massive ore, and disseminated ore (Chimimba, 1981). The massive ore is restricted to the contact between mineralized serpentinite and a competent lithology such as the banded iron-formation; it appears to be the product of remobilization. Partly massive ore, on the other hand, is thought to be an abnormal primary concentration of immiscible sulphides at the base of the flow or sill and is overlain with a sharp contact by the disseminated ore the dominant ore type.

The major minerals in all three ores are pentlandite, pyrrhotite, millerite, and chalcopyrite. Chimimba (1981) has suggested that the ultramafic rocks were extrusive, using the presence of the interlayered iron-formation as evidence, but metamorphism and deformation appear to have destroyed any supporting textural evidence of extrusion such as spinifex textures or flow-top breccias. Whether as flows or sills or both, the sulphide minerals have settled as immiscible droplets and now form part of the intercumulus phase surrounding relict olivine crystals.

\section{Epoch Mine}

The Epoch Mine, situated close to Filabusi, occurs in the same stratigraphic interval as the Trojan deposit. It was found in 1969 as a result of the systematic exploration (using soil geochemistry) of an exclusive prospecting area. The orebody forms part of a layered differentiated complex which intrudes the underlying felsic schists and protrudes into the overlying tholeiitic greenstones and minor banded ironformation (Baglow, 1980; Baglow and Ncube, 1981). The basal olivine (now serpentine-rich) units are overlain by metamorphosed pyroxenites and gabbro/norite. The four ore zones are defined on a grade cut-off, and the total ore reserves currently stand at nearly five million tonnes grading $0.64 \% \mathrm{Ni}$.

The mineralogy of the ore is unusual for Zimbabwe in that millerite forms a common component, particularly in the hanging wall side of the ore zone. Pentlandite, polydymite, and chalcopyrite are also major minerals and all occur as disseminations which are locally concentrated into small pods EPISODES, Vol. 1981, No. 2. and veinlets. The textural evidence suggests the separation of sulphide into an immiscible phase and subsequent settling as intercumulus liquid.

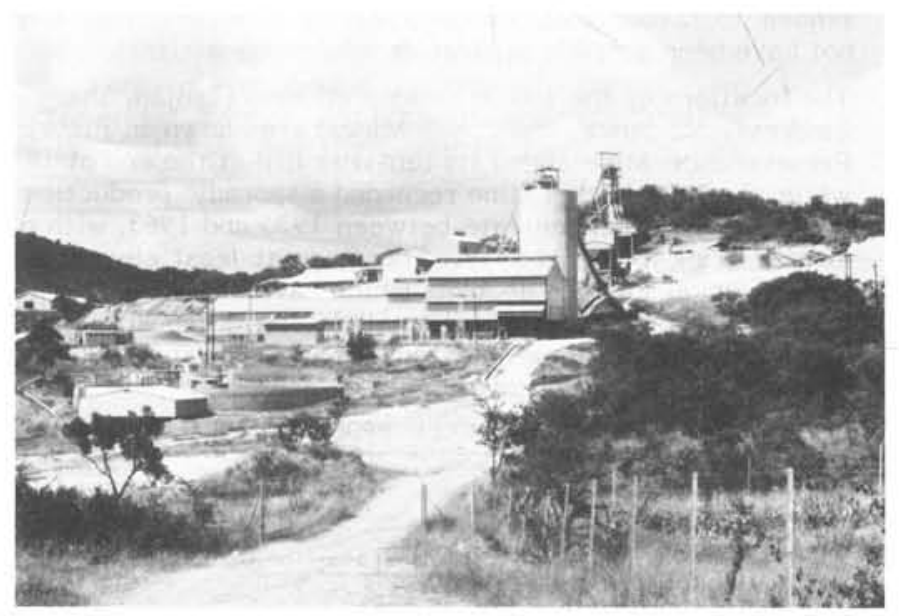

Headf rame and mill at Epoch Mine, Zimbabwe.

\section{Shangani Mine}

Shangani is one of three orebodies to have been discovered by systematic geochemical exploration. It lies close to the village of the same name on the northern perimeter of the Shangani greenstone belt. The regional geology has been described by Harrison (1969) and comprehensive accounts of the mine and its surroundings have been presented by Viljoen et al. (1976) and Viljoen and Bernasconi (1979).

The mine started operating in 1976, and total ore reserves now stand at 14.7 million tonnes containing $0.80 \%$ nickel Initially, the mine was open-cast, although the operations are now being transferred underground.

The local stratigraphy around Shangani comprises the basal Esmyangene Formation of felsic pyroclastic rocks, succeeded by ultramafic rocks of the Makwe Formation, which in turn are overlain by the thick tholeiitic pile of the Ensangu Formation. Viljoen et al. (1976) place the two lower Formations within the Sebakwian Group and assign the Ensangu Formation to the Bulawayan. Williams (1979) has suggested, however, that the ultramafic or komatiitic Makwe Formation should also be part of the Bulawayan; this is supported by Wilson (1979), though he places the Esmyangene Formation (and the underlying Leechdale Formation) in the Lower Greenstones rather than the Sebakwian.

The mineralized complex which contains the Shangani ore bodies is roughly mushroom-shaped in plan and continues for at least $1.7 \mathrm{~km}$ along a moderate south-easterly plunge. It is intrusive into the felsic rocks of the Esmyangene Formation but is considered by Williams (1979) to be part of a volcanic vent feeding the overlying komatiitic flows of the Makwe Formation.

The actual ore zones within this complex are confined to its stratigraphically flat-lying parts - in two lobes adjacent to the stem of the "mushroom". The sulphides are massive on the underside of the lobes, with disseminations occurring higher up. Pyrrhotite and pentlandite are the major sulphide minerals together with minor pyrite and chalcopyrite.

Although the origin of the Shangani Complex as a volcanic vent is unusual, a number of features link it to the deposits of Trojan, Epoch, and Damba. Firstly, the stratigraphic setting is clearly related to the early phases of volcanism in the Upper Greenstones. Secondly, the magma from which the ore bodies formed is komatiitic in composition with very high nickel to copper ratios. Finally, the sulphides have segregated as droplets which accumulated upon any convenient near-horizontal surface, in this case a lobe of magma adjacent to or forming part of a volcanic vent. 


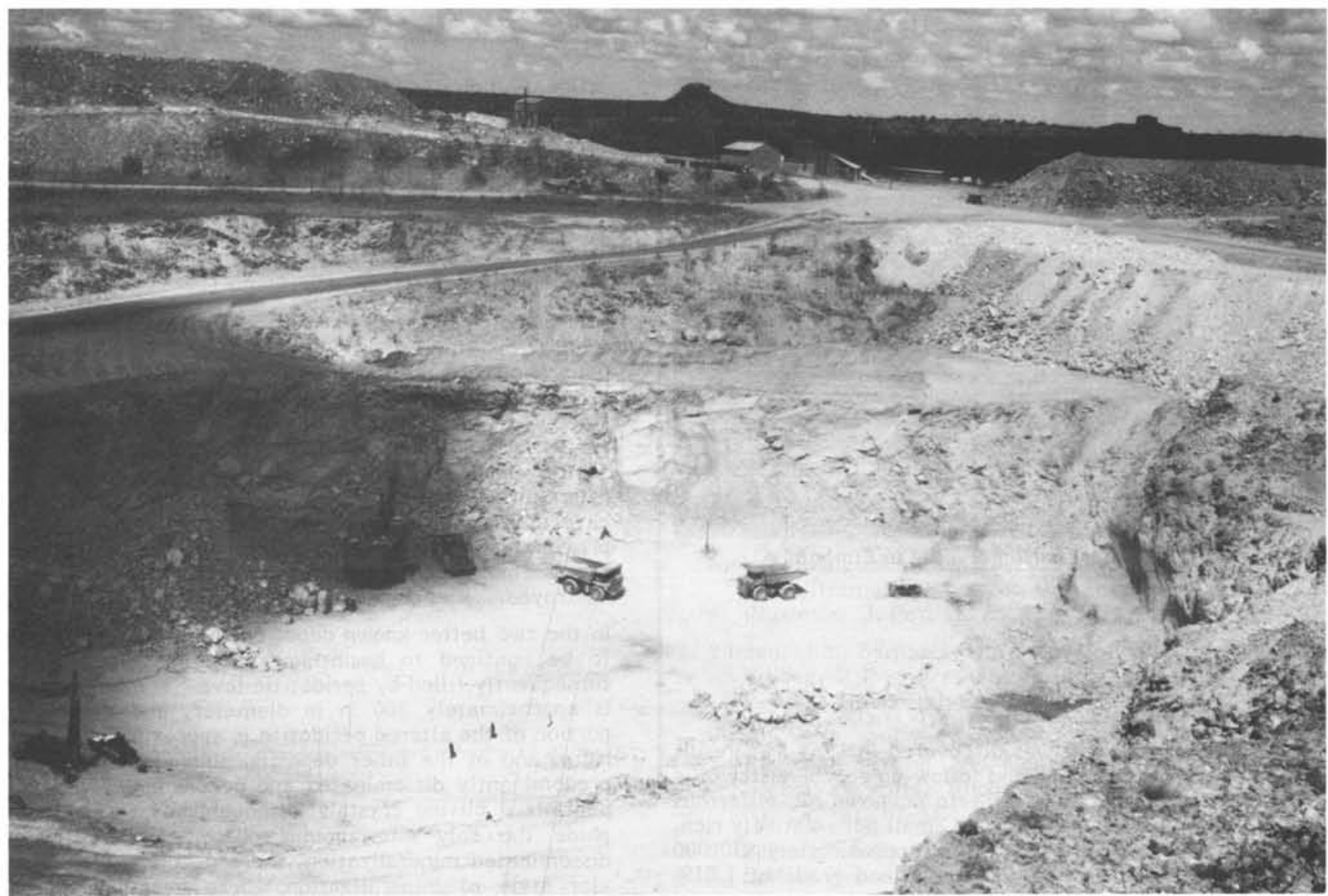

An open pit, Shangani Mine, Zimbabwe.

\section{Madziwa Mine}

The Madziwa nickel sulphide orebodies occur within metamorphosed mafic and ultramafic rocks of the Madziwa Complex, which consists of several discrete bodies intruding Archaean granite rocks $150 \mathrm{~km}$ NE of Salisbury. The age of the complex is probably Archaean, but as it is surrounded by granitic rocks, no attempt has been made at correlating it with the regional stratigraphy.

The first nickeliferous gossan from the area was found in 1958 and sulphide mineralization was proved in a shaft prior to the property being bought by a company. This led to the production of the first concentrates in 1968 from two separate orebodies known as Amm's and Sulphide Hill. The current reserves of the mine only total 3.5 million tonnes with a grade of $0.61 \%$ nickel; significant copper is also present. Despite exploration for orebody extensions, none have yet been discovered.

The rocks comprising the Madziwa Complex (Gewald, 1974; Chimimba, 1981) are dominantly metapyroxenite and metagabbro. The contact between the two is irregular, in a northwesterly direction, parallel to the elongation of the mafic pods. At Amm's, the metapyroxenite forms a core to the metagabbro, and a similar relationship is indicated at Sulphide Hill. The mafic pods comprising the Madziwa Complex are thought to intrude the gneiss and have suffered subsequent metamorphism but little deformation.

The orebodies generally parallel the overall north-westerly trend, commonly transgressing lithological contacts, although they are wholly contained within the complex. The nickel and copper sulphides are mostly interstitial to the silicates, but massive ore is also present in tension fractures (joints) as stringers in disseminated ore and as thin pods along some lithological contacts. Pyrrhotite, pentlandite, and chalcopyrite are the major ore minerals with lesser violarite, millerite, sphalerite, polydymite, and carrollite.

The origin of the mineralization at Madziwa is obscure. It is assumed that primary separation of immiscible sulphide liquid took place, followed by some secondary concentration of these sulphides.

EPISODES, Vol. 1981, No. 2.

\section{Empress Nickel Mine}

The Empress Nickel Mine was the first sulphide deposit to be discovered in Zimbabwe. It lies some $60 \mathrm{~km} \mathrm{SW}$ of Gatooma where, on the surface, it occurs as a dyke-like feature of nickeliferrous rocks extending for over $800 \mathrm{~m}$ along the SW edge of a small elongate granitic stock (Anderson, 1979). Current ore reserves amount to some 8.7 million tonnes carrying $0.72 \%$ nickel and $0.56 \%$ copper.

The ore is contained within a mafic-ultramafic assemblage which appears to be a differentiated sill conformably intrusive into the calc-alkaline suite forming the uppermost unit of the Bulawayan Group (Wilson, 1979). All of these rocks are deformed and metamorphosed and intruded by the granitic stock.

The footwall to the orebody consists essentially of felsic volcanic rocks with some sulphide-bearing agglomerate. The hanging wall consists of dioritic material containing illdefined melanocratic zones and fragments of footwall volcanics.

Mineralization is confined to peridotites and gabbros, now largely altered, which exhibit a crude layering. The sulphide minerals are pyrrhotite, pentlandite, and chalcopyrite with lesser primary and secondary magnetite. The nickel to copper ratio is approximately one.

Sulphide mineralization is either of a fine interstitial type, coarse and "blebby", or a massive or semi-massive type occuring in stringers and veinlets. The fine interstitial type is confined to the periodotite, whereas the blebby mineralization occurs in the gabbro; veinlets are present throughout and are even found in the footwall country rock.

Despite the metamorphic and tectonic events which have obscured the finer primary features, the origin of the orebody appears to be in the segregation of immiscible sulphides during differentiation of a large sill, probably of mafic composition. 


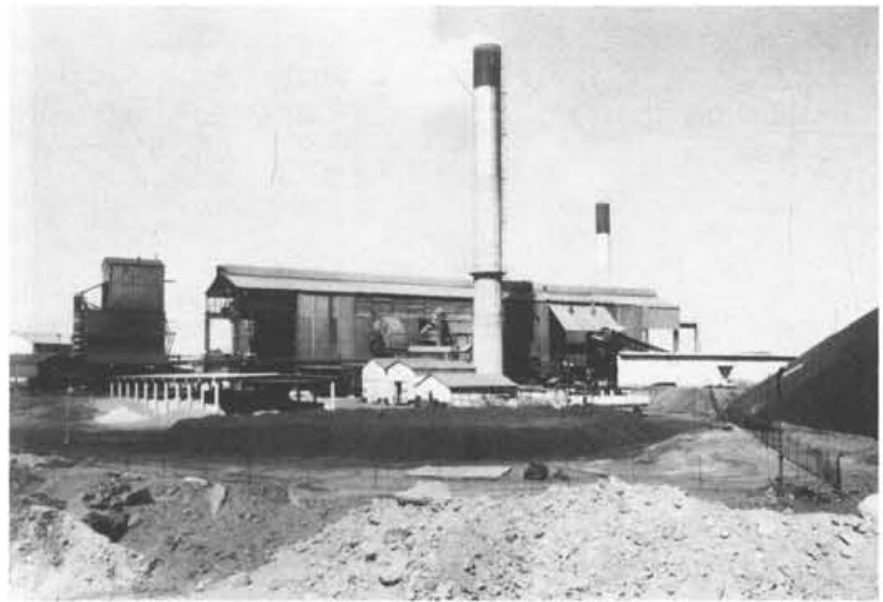

The smelter at the Empress Nickel Mine in Zimbabwe.

\section{Perseverance Mine}

The Perseverance deposit was discovered in 1964 as a result of stream sediment sampling and follow-up geochemistry on a grid pattern which led to a hitherto unknown nickeliferrous gossan. The orebodies proved to be small but relatively rich, and when production ceased in 1980, approximately 830000 tonnes of ore had been milled with a head grade of $1.01 \%$ nickel and $0.4 \%$ copper.

The regional geology has been described by Bliss (1966); Wilson's (1979) re-interpretation of the stratigraphy places Perseverance within the bimodal suite of the Bulawayan Group. It is the only nickel mine to be located within this stratigraphic interval, although komatiitic rocks are locally well-developed elsewhere along strike. The orebodies are mostly confined to a mafic lava sequence containing local developments of black shale and chert (Anderson et al., 1979). Below the lava pile there is a thick sequence of felsic to intermediate pyroclastic rocks and its hanging wall is transgressed at a low angle by a thick differentiated ultramafic body.

There were two distinct orebody types, designated the Main and Hanging Wall bodies. The Main orebody was lenticular in shape and had a central bulge which split into two discrete units surrounded by the mafic lavas. Most of the ore was disseminated, although lenses of a massive type were also present. The ore minerals, pyrrhotite, pentlandite, and pyrite, were hosted largely by a talc-antigorite rock with some meta-andesite locally present. The nickel to copper ratios within the talcose host was found to be $3: 1$, whereas that of the massive ore was $4: 1$; where andesitic rocks hosted the mineralization, the ratio was $1: 1$.

The Hanging Wall orebody was located at the base of the thick, differentiated ultramafic sill which intrudes the lava sequence. Here pockets of disseminated ore were confined to basin-like traps or warps in the floor of the sill (Anderson et al., 1979). The nickel to copper ratio was $4: 1$.

Anderson et al. (1979) discuss the origin of the Perseverance mineralization as the settling of immiscible sulphides within an intrusive sill for the Hanging Wall body. The genesis of the Main body is less clear; they suggest that the sulphidebearing ultramafic lenses may be of volcanic origin, a sill cogenetic with the volcanic sequence, or an off-shoot of the Hanging Wall ultramafic sill.

\section{Damba Deposits}

The Damba area lies some $75 \mathrm{~km} \mathrm{~N}-\mathrm{NE}$ of Bulawayo. Its geology was first described by McGregor (1928) and the discovery by prospectors of nickel gossan in 1968 led to the EPISODES, Vol. 1981, No. 2. delineation of five separate deposits by subsequent geochemical and geophysical prospecting. Two of these have been extensively drilled and are described in detail by Williams (1979). The orebodies are confined to the base of the Upper Greenstones of the Bulawayan Group (see Williams, 1979, for an alternative opinion). The lithological units described by Williams closely fit the stratigraphy shown in Table 1 if one uses current definitions of komatiite (Arndt and Nisbet, in press) rather than those of Williams (1979).

At Damba, there is a $750 \mathrm{~m}$ thick komatiitic succession (units 1 and 2 of Williams, 1979) overlain by a thick tholeiitic pile (unit 3). The deposits occur along a strike of more than $7 \mathrm{~km}$ in length, in a northerly direction. The succession then dips steeply to the west. The lowermost units are generally peridotitic and spinifex textures and flow top breccias attest to the essentially extrusive nature of these rocks, although relict olivine phenocrysts may also be present. The rocks have undergone low grade regional metamorphism and comprise serpentinite, carbonated serpentinite and talc-carbonate assemblages. In general, the primary textures have been destroyed.

In the two better known deposits, the mineralization appears to be confined to basin-like depressions in a palaeofloor subsequently filled by peridotitic lava. The larger depression is approximately $500 \mathrm{~m}$ in diameter, and the mineralized portion of the altered peridotite is approximately $75 \mathrm{~m}$ thick. Here, and in the other deposits, sulphide mineralization is predominantly disseminated and occurs between wholly serpentinized olivine crystals, although only rarely is the sulphide the only intercumulus phase. In addition to the disseminated mineralization, there occurs a blebby or globular style of mineralization where irregular spheroids of variable size (up to $20 \mathrm{~mm}$ ) are considered to be either amygdaloidal fillings or rounded immiscible droplets.

Sulphide minerals also occur in veinlets believed to have resulted from later remobilization. Exploration of the nickel deposits at Damba is continuing, but as yet there is no published information concerning possible reserves or grades.

\section{Hunters Road Deposits}

At Hunters Road, Moubray et al. (1979) have described a serpentinite "dyke" containing "xenoliths" of banded ironformation which has intruded felsic lavas and pyroclastic rocks. In keeping with other deposits of this nature, the sulphides appear to have formed an immiscible phase and the host is contained within the lower parts of the Upper Greenstone stratigraphy. The mineralogy of pyrrhotite, pentlandite, pyrite, and chalcopyrite is also the same, the major difference being in the presence of several bands of platey spinifex textures, clearly indicating several thin intrusions or, more likely, flows. This is supported by the presence of the banded ironstone and the several parallel ore zones that were intersected in boreholes. Although a large reserve has been indicated for this deposit at a moderate grade, no mining of ore has as yet taken place.

\section{The Great Dyke}

The Great Dyke, one of the most remarkable geological features on Earth, is an elongate layered intrusion about 500 $\mathrm{km}$ long and up to $7 \mathrm{~km}$ wide. The lower parts show a cyclicity of the layering (Fig. 3) ending in the formation of a thick gabbro cap which appears above three of the four complexes making up the Dyke (Worst, 1960). Some $10 \mathrm{~m}$ below the base of this gabbro occurs the main (though not the only) base metal horizon containing, on average, $0.25 \%$ nickel and $0.20 \%$ copper. These values are not quite coincident with the enrichment of the platinum group metals but are within stoping width distance of them.

Although these horizons have been known for a long time, it is only in the past decade that a serious effort to exploit the metals has been attempted. Even now, mining and extraction present problems that are not fully overcome. 


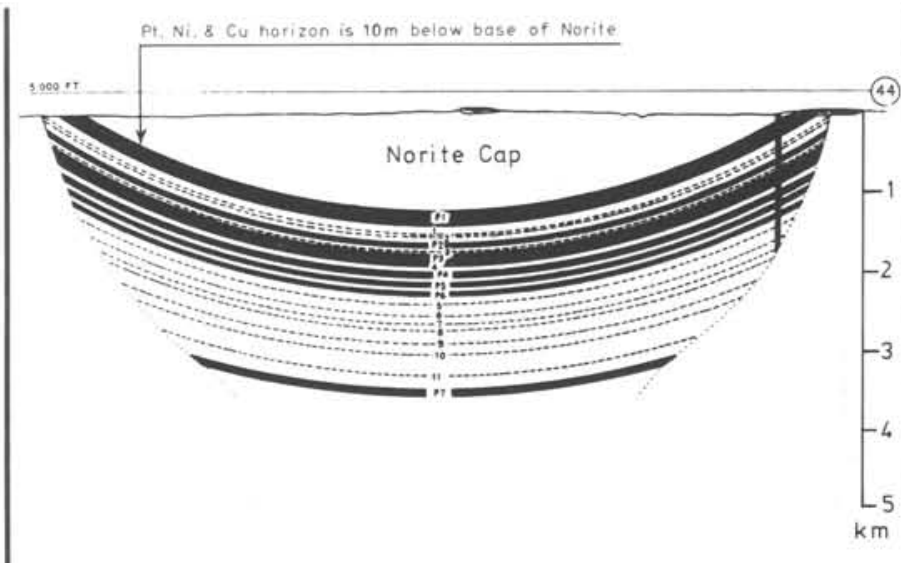

Section through THE GREAT DYKE - ZIMBABWE

(after B.G.Worst - Geol.Survey Bulletin No 47 - 4 .)

Figure 3.

\section{Lateritic Deposits}

The climate of Zimbabwe is not conducive to the formation of nickel laterites, although they do occur in some areas. The minerals are mostly silicates which form cappings to the Archaean serpentinites and those of the Great Dyke. The floors of these deposits, however, are likely to be uneven and the laterite cover is thin. Very careful mining would be required to prevent contamination by refractory serpentine. This, compounded with their relatively low grade (compared to deposits in tropical climes) and the high extraction costs, make them a potential resource for the future.

\section{Summary}

Three of the five producing mines and a large proportion of the more promising prospects occur within a komatiitic sequence near the base of the Upper Greenstones of the Bulawayan Group. For all deposits, the accumulation of immiscible sulphide droplets appears to be the primary concentrating factor of nickel. All of the deposits in greenstone belts are intimately associated with sulphide facies, ironformation, or sulphide-bearing tuffs, which may represent a source of sulphur for "fixing" nickel in the silicate melt into a form that can be naturally concentrated.

Lateritic nickel deposits are small and exploitation is unlikely despite the generally higher grades of these deposits compared to the sulphide orebodies. Although the Great Dyke contains considerable resources of nickel together with the platinum group and other metals, extraction from this source on a large scale may have to await a more favourable economic climate. The greatest potential for finding new nickel deposits lies within the komatiitic rocks of the Upper Greenstones of the Bulawayan Group.

\section{References}

Anderson, I.G., 1979, The geology of the Empress Nickel Mine: Unpubl. Report, Rio Tinto (Zimbabwe) Ltd.

Anderson, I.G., Varndell, B.J. and Westner, G.J., 1979, Some Geological Aspects of the Perseverance Nickel Deposit, Rhodesia: Spec. Pub. Geol. Soc. S. Afr., 5, p. 99-107.

Arndt, N.T. and Nisbet, E.G., 1981, Komatiites: George Allen and Unwin, in press.

Baglow, N., 1980, The Geology of the Epoch Nickel Mine: Unpubl. Special Honours Project, University of Zimbabwe.

EPISODES, Vol. 1981, No. 2.
Baglow, N. and Ncube, S., 1981, The Geology of the Epoch Nickel Mine: Unpubl. Report, Inst. Of Mining Research, University of Zimbabwe.

Chimimba, L.R., 1981, The Geology of the Trojan Nickel Deposit: Unpub. Report, Anglo American Corporation.

Chimimba, L.R., 1981, The Madziwa Nickel-Copper Deposits: Unpubl. Report, Anglo American Corporation.

Gewald, H., 1974, The mineralisation at the Madziwa Mine. Rhodesia: Unpubl. Ph.D. Thesis, University of London, 233p.

Harrison, N.M., 1969, The geology of the country around Fort Rixon and Shangani: Bull. Geol. Surv. Rhod., 61, 132p.

MacGregor, A.M., 1928, The geology of the country around the Lonely Mine, Bubi District: Bull. Geol. Surv. S. Rhod., $11,96 \mathrm{p}$.

Moubray, R.J. et al., 1979, The Hunters Road Nickel Prospect: Geol. Soc. S. Africa, Spec. Pub. 5, p. 109-116.

Nisbet, E.G., Bickle, M.J. and Martin, A., 1977, The Mafic and Ultramafic Lavas of the Belingwe Greenstone Belt, Rhodesia: J. Pet, 18, no. 4, p. 521-566.

Viljoen, M.J., Bernasconi, A., Van Coller, N., Kunloch, E., and Viljoen, R.P., 1976, The Geology of the Shangani Nickel Deposit, Rhodesia: Econ. Geol. 71, p. 76-95.

Viljoen, M.J. and Bernasconi, A., 1979, The Geochemistry, Regional Setting and Genesis of the Shangani-Damba Nickel Deposits, Rhodesia: Spec. Pub. Geol. Soc. S. Africa, 5, p. 67-98.

Williams, D.A.C., 1979, The Association of Some Nickel Sulfide Deposits with Komatiitic Volcanism in Rhodesia: Canadian Mineralogist, 17, p. 337-349.

Wilson, J.F., 1979, A Preliminary Reappraisal of the Rhodesian Basement Complex: Spec. Pub. Geol. Soc. S. Africa, 5, p. 1-23.

Worst, B.G., 1960, The Great Dyke of Southern Rhodesia: Bull. Geol. Surv. S. Rhod., 47.

\section{ABOUT THE AUTHORS:}

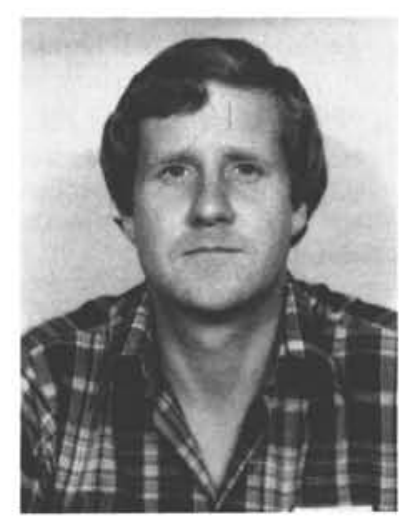

Dr. R.P. Foster

Dr. R.P. (Bob) Foster is is a Senior Geologist with the Institute of Mining Research, University of Zimbabwe in Salisbury. His current research interest is in synthesizing the available information on the distribution and genetic problems of gold mineralization.

Dr. A. (Tony) Martin lectures in the Department of Geology, University of Zimbabwe. His prime research interests are in Archean stratigraphy. Dr. Martin was previously employed by the Geological Survey of Rhodesia and was responsible for mapping the northern section of the Belingwe greenstone belt.

Dr. J.M. (John) Clutten is Chief Geologist for Anglo American (Zimbabwe) Ltd., which operates many of the nickel mines in Zimbabwe. Prior to joining this company, he was engaged in 